Annals of Plant and Soil Research 23(1): 66-70 (2021)

https://doi.org/10.47815/apsr.2021.10031

\title{
Effect of biostimulants on the yield of bush bean (Lablab purpureus var. typicus)
}

\author{
V. M. PRIYADARSHINI AND P. MADHANAKUMARI \\ Department of Horticulture, Faculty of Agriculture, Annamalai University, Annamalai Nagar-608002 (Tamil \\ Nadu) India
}

Received: August, 2020; Revised accepted: October, 2020

\begin{abstract}
A field experiment was conducted assess the influences of biostimuants on the yield of bush bean $\mathrm{cv}$. Co (Gb) 14 at Poothurai village, Tamil Nadu during kharif season of 2019 in randomized block design with nine treatments and three replications. Biostimulants adopted for the study were seaweed extract, panchagavya, chitosan and effective microorganism with two different concentrations applied as foliar spray on 30, 45 and 60 days after sowing.Results revealed that the maximum values of yield parameters viz., length of the raceme(51.2 $\mathrm{cm})$, number of racemes plant ${ }^{-1}(8.5)$, number of flowers raceme ${ }^{-1}$ (26.4), number of flowers (221.5), days to 50 $\%$ flowering (36.6 days), number of pods plant $t^{-1}(41.6)$, pod length $(10.6 \mathrm{~cm})$, pod width $(3.2 \mathrm{~cm})$, single pod weight (4.6 g), number of seeds (5.2), total pod yield (12.6 t/ha), net income (Rs. 1,71,628 ha ${ }^{-1}$ ) and B:C ratio (3.14)were recorded under the treatment of seaweed extract $\left(5 \mathrm{~mL}^{-1}\right)+R D F$. The $R D F+3 \%$ panchagavya proved next best treatment in respect of these parameters. Among all the biostimulants, seaweed proved superior to others in respect of flowering and yield attributes. The minimum values of all these characters were recorded under control.
\end{abstract}

Keywords: Bush bean, biostimulants, yield, cost economics

\section{INTRODUCTION}

Hyacinth bean or bush bean or dolichos lablab (Lablab purpureus var. typicus) isone of the important crop among the cultivated legumes in India. Bush bean is used as pulse, vegetables and fodder. It is rich in protein and occupies a unique position as vegetable among the legumes due to its high nutritive value.Modern agricultural practices purely depend on chemical fertilizers to increase crop production which adversely affects the soil efficiency and also have huge impacts on human health (Rengasamy et al., 2015). Use of chemical fertilizers along with growth enhancing biostimulants increases the productivity of the crop as well as enhances the soil fertility and reduces the cost of production. In this context, liquid seaweed extract has gained popularity in the world where marked increase is observed in the commercial utilization of seaweed extract. Seaweed extract exhibit growth stimulating property, as they contain macro nutrients, trace elements, organic substances like amino acids and plant growth regulators such as auxin, cytokinin and gibberellins (Spinelli et al., 2010). Chitosan, extracted from the exoskeleton of crustaceans have fungicidal effects, elicitation in defense mechanism and regulates gaseous exchange (Shehataet al., 2012). Panchagavya enhances the biological efficiency of crops, activates biological reactions and protects plants from diseases (Nileema and Sreenivasa, 2011). Effective microorganism improves the physical, chemical and biological environment of soil, suppresses soil borne pathogen and pest, enhance photosynthetic capacity of crops (Olle and Williams, 2013). Thus, an experiment was conducted to study the role of these biostimulants in combination with inorganic fertilizers on the growth and yield of bush bean.

\section{MATERIALS AND METHODS}

The field experiment was conducted at Poothurai village, Vanur taluk, Villupuram district of Tamil Nadu during kharif season of 2019. The field area consists of red soil with excellent water holding capacity. It has a pH of about 8.02 and electrical conductivity of $0.13 \mathrm{dSm}^{-1}$. The experiment was laid out in randomized block design with nine treatments and three replications. The treatments comprised of $T_{1}$ : Control, $\mathrm{T}_{2}$ : RDF + sea weed extract ( $3 \mathrm{ml} / \mathrm{litre}$ ), $\mathrm{T}_{3}$ : RDF + sea weed extract (5 ml/litre), $\mathrm{T}_{4}: \mathrm{RDF}$ + panchagavya $(3 \%), \mathrm{T}_{5}: \mathrm{RDF}+$ panchagavya (5\%), $\mathrm{T}_{6}: \mathrm{RDF}+$ chitosan $100 \mathrm{ppm}, \mathrm{T}_{7}: \mathrm{RDF}+$ chitosan $150 \mathrm{ppm}, \mathrm{T}_{8}$ : RDF + effective 
microorganisms (1:500) and $T_{9}$ : RDF + effective microorganism (1:1000). Foliar application of biostimulants was applied at 30,45 and 60 days after sowing. The recommended dose of fertilizers $\left(25 \mathrm{~kg} \mathrm{~N}+50 \mathrm{Kg} \mathrm{P}_{2} \mathrm{O}_{5} \mathrm{ha}^{-1}\right)$ was applied as basal. Bush bean variety selected for study was Co $(\mathrm{Gb})$ 14. The seeds were sown after seed treatment with rhizobium at a spacing of 45 $x 30 \mathrm{~cm}$ in ridges and furrows with a depth of 2 $\mathrm{cm}$. The cultural operations viz.,field operation, application of manures, seed treatment, seed sowing, irrigation, thinning, hand weeding,earthing up and staking were carried out as per the requirement of the crop.The observations on length of the raceme, racemes plant $^{-1}$, flowers raceme ${ }^{-1}$, flowers plant ${ }^{-1}$, days to $50 \%$ flowering, pods plant $^{-1}$, pod length, pod width, single pod weight, seeds pod $^{-1}$, total pod yield were recorded at harvest.The data were recorded by taking five plants from each plot which was selected randomly. The statistical analysis of data was done by using DSAASTAT. For treatments showing significance, critical differences were worked out at five percent probability level. Net incomewas obtained by deducting all costs from gross income. $\mathrm{B}$ : $\mathrm{C}$ ratio was calculated by dividing the gross income with total cost of cultivation.

\section{RESULTS AND DISCUSSION}

\section{Flowering characters}

The length of the raceme was found to be maximum $(51.2 \mathrm{~cm})$ with RDF + sea weed extract $5 \mathrm{ml} / \mathrm{l}$, which was followed by $49.5 \mathrm{~cm}$ with RDF + panchagavya @ 3\% and $47.9 \mathrm{~cm}$ in RDF + effective microorganism 1:1000. The minimum length of raceme $(36.2 \mathrm{~cm})$ was recorded in control.The highest number of racemes plant ${ }^{1}(8.5)$ was reported in sea weed extract @ $5 \mathrm{ml} / \mathrm{l}$ along with RDF. It was followed by 7.9 and 6.9 which received panchagavya @ 3\% along with RDF and effective microorganism @ 1:1000 along with RDF, respectively. The lowest number of racemesplant $^{-1}$ (5.1) was recorded in control. The maximum number of flowers raceme 1 (26.4), number of flowers plant ${ }^{-1}$ (221.5) and days taken for $50 \%$ flowering (36.6 days) were recorded in RDF + sea weed extract @ 5ml/l. This was followed by 24.5 flowers raceme ${ }^{-1}$, 191.3 flowers plant $^{-1}$ and 38.3 days for $50 \%$ flowering with RDF $+30 \%$ panchagavya. The minimum number of flowers raceme ${ }^{-1}$ (15.4), number of flowers plant ${ }^{-1}$ (79.2) and days to 50 $\%$ flowering (47.5 days) were observed in control.The flowering characters (Table 1) were found to have a positive response due to the application of sea weed extract.

It may be because, at the onset and development of flowering, the number of flowers produced is linked to the developmental stages of plants. Seaweed extracts probably encourage flowering by initiating robust plant growth (Sridhar and Rengasamy, 2010).This may be due to the presence of hormonal substance in seaweed liquid extract, especially cytokinins. The presence of higher amount of potassium than other micro-nutrients and growth regulators probably stimulate flower initiation and enhance the number of flowers per plant.In panchagavya, due to better source-sink relationship,due to increased vegetative growth there were more number of flowers leading to improved flowering characters.

Table 1: Influence of biostimulants on the flowering characters of bush bean

\begin{tabular}{|c|c|c|c|c|c|}
\hline Treatments & $\begin{array}{l}\text { Length of raceme } \\
(\mathrm{cm})\end{array}$ & $\begin{array}{l}\text { Racemes } \\
\text { plant }^{-1}\end{array}$ & $\begin{array}{c}\text { Flowers } \\
\text { Racemes }^{-1}\end{array}$ & $\begin{array}{l}\text { Flowers } \\
\text { Plant }^{-1}\end{array}$ & $\begin{array}{l}\text { Days to } 50 \\
\% \text { flowering }\end{array}$ \\
\hline $\mathrm{T}_{1}$ - Control & 36.2 & 5.1 & 15.4 & 79.2 & 47.5 \\
\hline $\mathrm{T}_{2}-\mathrm{RDF}+\mathrm{SWE}(3 \mathrm{ml} /$ /itre $)$ & 44.8 & 6.2 & 20.5 & 127.3 & 43.1 \\
\hline $\mathrm{T}_{3}-\mathrm{RDF}+\mathrm{SWE}(5 \mathrm{ml} / \mathrm{litre})$ & 51.2 & 8.5 & 26.4 & 221.5 & 36.6 \\
\hline $\mathrm{T}_{4}-\mathrm{RDF}+$ Panchagavya (3\%) & 49.5 & 7.9 & 24.5 & 191.3 & 38.3 \\
\hline $\mathrm{T}_{5}-\mathrm{RDF}+$ Panchagavya (5\%) & 43.8 & 6.0 & 19.7 & 118.6 & 43.8 \\
\hline $\mathrm{T}_{6}-\mathrm{RDF}+$ Chitosan $100 \mathrm{ppm}$ & 41.9 & 5.7 & 18.2 & 102.2 & 44.8 \\
\hline $\mathrm{T}_{7}-\mathrm{RDF}+$ Chitosan $150 \mathrm{ppm}$ & 46.3 & 6.6 & 21.7 & 142.4 & 41.6 \\
\hline $\mathrm{T}_{8}-\mathrm{RDF}+\mathrm{EM}(1: 500)$ & 40.9 & 5.5 & 17.4 & 94.2 & 45.5 \\
\hline$T_{9}-R D F+E M(1: 1000)$ & 47.9 & 6.9 & 23.0 & 157.9 & 40.0 \\
\hline S.Ed & 0.68 & 0.15 & 0.15 & 4.88 & 0.79 \\
\hline C.D $(p=0.05)$ & 1.44 & 0.32 & 0.32 & 10.34 & 1.57 \\
\hline
\end{tabular}


The easy transfer of nutrients to plants through foliar spray and the quantities of IAA and GA present in panchagavya, could have created a stimuli in plant system, which in turn increased the production of growth regulators in cell system, stimulating better flowering. The third best was observed in treatment receiving effective microorganism at 1:1000 concentration. This is because, application of EM enhances the decomposition of organic fertilizers and nutrient uptake quickly when compared to others (Khaing and Kyu, 2016).

\section{Pod characters}

The number of pods (Table 2) was found to be maximum (41.6) with RDF + sea weed extract @ 5ml/l, 39.5 in RDF + panchgavya @ 3 $\%$ and 37.9 RDF + effective microorganism @ $1: 1000$. It was minimum (32.1) in control. The treatment receiving sea weed extract @ 5ml/l along with RDF was found to exhibit positive response on length $(10.6 \mathrm{~cm})$ and breadth $(3.2$ $\mathrm{cm}$ ) of the pod. It was followed by RDF + panchagavya @ $3 \%$ with $9.9 \mathrm{~cm}$ for length and $3.1 \mathrm{~cm}$ for breadth and RDF + effective microorganism @ 1:1000 with 8.9 cm for length and $2.9 \mathrm{~cm}$ for breadth. The least values were found in control which recorded $6.0 \mathrm{~cm}$ for length and $2.3 \mathrm{~cm}$ for breadth. The highest single pod weight $(4.6 \mathrm{~g})$ was observed with foliar application of sea weed extract @ $5 \mathrm{ml} / \mathrm{l}$ along with RDF. It was followed by $4.3 \mathrm{~g}$ and $4.0 \mathrm{~g}$ with panchagavya @ $3 \%$ along with RDF and effective microorganism @ 1:1000 along with RDF respectively. The single pod weight was minimum $(3.0 \mathrm{~g})$ with control. The seeds pod $^{-}$ ${ }^{1}(5.2)$ were found maximum in RDF + sea weed extract @ 5ml/l, followed by 5.1 in RDF + 3\% panchagavya and 5.0 seeds in RDF + Effective microorganism @ 1:1000. The lowest number of seeds (4.2) was recorded in control.

This response on pod characters as a result of application of sea weed extract may be due to the effect of cytokinins present in seaweed extracts. There are two ways by which seaweed caused pod weight increment. Firstly, increase in the source capacity of leaves led to increasing the supply of assimilates those permitted pod filling. This could be achieved by increasing leaf area or photosynthetic rates.Secondly, applying seaweed could have increased pod weight by increasing the sink potential of beans for assimilates. They suggested an increment in cotyledon cell number and thus final pod mass. This was similar to the findings of Paramanicket al. (2013) and Youssef et al. (2019).Application of panchgavya@ @ 3 \% has been found to be the second best in pod characters. This might be due to relatively higher amount of carbohydrates could have promoted the growth rate and in turn increased the number of pods, single pod weight and other pod characters. The increase in fruit weight might be due to better mineral utilization of plants accompanied with enhancement of photosynthesis, other metabolic activity and greater diversion of food material to fruits. This was in accordance with the result of Narayanammaet al., (2009) in bitter gourd. According to Moraditochaee et al (2011), the nitrogen content present in effective microorganisms have found to fulfil the requirement of $\mathrm{N}$ and thereby increasing the number of pods.

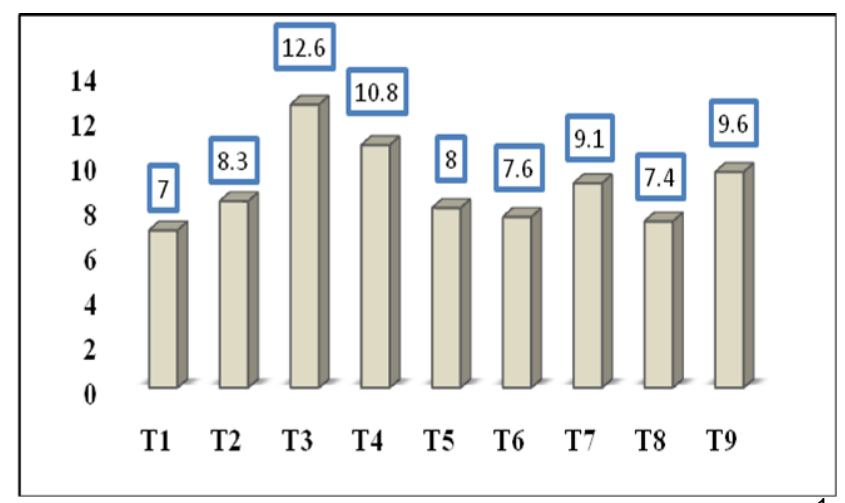

Fig. 1: Effect of biostimulants on pod yield $\left(\mathrm{t} \mathrm{ha}^{-1}\right)$

\section{Yield parameter}

The total pod yield (12.6 $\left.\mathrm{t} \mathrm{ha}^{-1}\right)$ was recorded highest in treatment receiving the application of sea weed extract @ $0 \mathrm{ml} / \mathrm{l}$ along with RDF. It was followed by RDF + panchagavya @ $3 \%$ with total pod yield of $10.8 \mathrm{t} \mathrm{ha}^{-1}$ and RDF + effective microorganism @ 1:1000 with total pod yield of $9.6 \mathrm{t} \mathrm{ha}^{-1}$. The lowest values $(7.0 \mathrm{t}$ $\mathrm{ha}^{-1}$ ) of yield were found in control.The increase in yield and yield attributes (Table 2) is due to the presence of reasonable quantity of macro and micro nutrients in sea weed extract. Sea weed extract stimulates yield as they contain stimulators such as auxin, gibberellins, cytokinins, trace elements, vitamins and amino acids. Yield increase in sea weed treated plants is thought to be associated with the hormonal substance present in the extracts, especially 
cytokinins. Cytokinin in vegetative plant organs are associated with nutrient partitioning, whereas in reproductive organs, high levels of cytokinin may be linked to nutrient mobilization. Cytokinin in sea weed extract shifts distribution of photosynthate from vegetative parts to the developing pods and promote pod development, producing pods with superior quality. The results were to be in parallel with the findings of Chatterjee and Thirumdasu (2014), Divya et al., (2015), Kocira et al., (2019) and Kharbyngar et al., (2019). Panchagavya @ 3\% has found to be the second best in better utilization of leaf nitrogen and efficient photosynthetic activity improving the yield (Sarkar, 2014). The higher pod yield in the above treatment may be due to the growth promoting substances present in panchagavya spray, which has enhanced the flower production, reduced ovary abortion, reduced flower and fruit drop, Hence it could able to set more number of fruits. The results are analogous to those reported by Gayathri et al., (2013) and Patilet al., (2012). The third best was treatment receiving effective microorganism @ $1: 1000$. EM has the ability to accelerate the decomposition of organic materials thereby released additional available nutrients which provided favourable conditions of rhizosphere for significantly increasing crop yield in EM sprayed plants when compared to control treatments (Seran and Shasheedaran, 2013).

Table 2: Pod, yield and cost economics of bush bean as influenced by biostimulants

\begin{tabular}{|c|c|c|c|c|c|c|c|}
\hline Treatments & $\begin{array}{l}\text { No. of } \\
\text { pods } \\
\text { plant }^{-1}\end{array}$ & $\begin{array}{l}\text { Pod } \\
\text { length } \\
(\mathrm{cm})\end{array}$ & $\begin{array}{l}\text { Pod } \\
\text { width } \\
\text { (cm) }\end{array}$ & $\begin{array}{c}\text { Single } \\
\text { Pod } \\
\text { Weight (g) }\end{array}$ & $\begin{array}{l}\text { No. of } \\
\text { Seeds } \\
\text { Pod }^{-1}\end{array}$ & $\begin{array}{c}\text { Net } \\
\text { Income } \\
(\text { Rs. ha-1) }\end{array}$ & $\begin{array}{l}\mathrm{B}: \mathrm{C} \\
\text { ratio }\end{array}$ \\
\hline $\mathrm{T}_{1}$ - Control & 32.1 & 6.0 & 2.3 & 3.0 & 4.2 & $64,819.4$ & 1.78 \\
\hline $\mathrm{T}_{2}-\mathrm{RDF}+\mathrm{SWE}(3 \mathrm{ml} /$ litre $)$ & 34.3 & 8.1 & 2.7 & 3.6 & 4.8 & $86,332.1$ & 2.08 \\
\hline $\mathrm{T}_{3}-\mathrm{RDF}+\mathrm{SWE}(5 \mathrm{ml} / \mathrm{litre})$ & 41.6 & 10.6 & 3.2 & 4.6 & 5.2 & $1,71,628.1$ & 3.14 \\
\hline $\mathrm{T}_{4}-\mathrm{RDF}+$ Panchagavya $(3 \%)$ & 39.5 & 9.9 & 3.1 & 4.3 & 5.1 & $1,35,815.3$ & 2.69 \\
\hline $\mathrm{T}_{5}-\mathrm{RDF}+$ Panchagavya (5\%) & 33.8 & 7.7 & 2.7 & 3.5 & 4.8 & $80,132.1$ & 1.99 \\
\hline $\mathrm{T}_{6}-\mathrm{RDF}+$ Chitosan 100ppm & 32.9 & 7.3 & 2.6 & 3.3 & 4.7 & $71,836.1$ & 1.89 \\
\hline $\mathrm{T}_{7}-\mathrm{RDF}+$ Chitosan 150ppm & 35.9 & 8.4 & 2.8 & 3.8 & 4.9 & $1,02,228.1$ & 2.27 \\
\hline $\mathrm{T}_{8}-\mathrm{RDF}+\mathrm{EM}(1: 500)$ & 32.4 & 6.9 & 2.5 & 3.2 & 4.7 & $67,877.7$ & 1.85 \\
\hline$T_{9}-R D F+E M(1: 1000)$ & 37.9 & 8.9 & 2.9 & 4.0 & 5.0 & $1,13,240.1$ & 2.42 \\
\hline S.Ed & 0.75 & 0.19 & 0.09 & 0.08 & 0.04 & - & - \\
\hline C.D $(p=0.05)$ & 1.59 & 0.40 & 0.04 & 0.17 & 0.08 & - & - \\
\hline
\end{tabular}

\section{Economics}

The net income (Rs. 1,71,628.1 ha ${ }^{-1}$ ) and BCR (3.14) was found to be maximum in treatment receiving seaweed extract @ $5 \mathrm{ml} /$ litre along with recommended dose of fertilizers. This was followed by panchagavya @ $3 \%$ with net income (Rs. 1,35,815.3 ha $^{-1}$ ) and BCR(2.69) and effective microorganism $(1: 1000)$ with net income (Rs. 1,13,340.1 $\mathrm{ha}^{-1}$ ) and BCR(2.42). Cost benefit (Table 2) of farmers was greatest when biostimulants was used as a growth promoter and proved as the cheapest along with higher net returns. Application of seaweed extract increased the overall growth as well as the yield characters due to the various active compounds present in them. Similarly, panchagavya and effective microorganisms also have the capacity to improve the yield due to the presence of macro and micro elements, hormones and bioactive compounds.

It may be concluded that the results strongly emphasis the role played by seaweed extract and other biostimulants in enhancing the yield and net returns of bush bean. With abundant distribution, great regeneration potential and easy mass cultivation, the seaweed biostimulant seems to be a feasible substitute to synthetic fertilizers. Apart from this, panchagavya and effective microorganism can also be further recommended to farmers for increasing the yield and enhancing the productivity of the crop thereby improving the livelihood of farmers. 


\section{REFERENCES}

Chatterjee, R. and Thirumdasu, R.K. (2014) Nutrient management in organic vegetable production.International Journal of Food, Agriculture and Veterinary Sciences 4: 156170.

Divya, K., Roja, M.N., and Padal, S.B. (2015) Effect of seaweed liquid fertilizer of Sargassumwightii on germination, growth and productivity of brinjal.International Journal of Advanced Research in Science, Engineerimg and Technology 2: 868-871.

Gayathri, K. and SyamSundar, P. (2013) Effect of integrated nutrient management $\mathrm{V}$. M. growth and yield of okra (Abelmoschusesculentus (L). Moench) Int.J.Curr.Microbiol.App.Sci (2017) 6(11): 918-924 924 cv. ArkaAnamika. Vegetable Science 40(2):246-248.

Khaing, M.M., and Kyu, K. (2016) Effects of priming tests and fertilizer applications on germination, growth and yields of chilli (Capsicum annum L), Hinthada University Research Journal 7: 97-105.

Kharbyngar, B. and Devi, S. (2019) Influence of seaweed extract organic and inorganic fertilizers on growth and yield of cauliflower (Brassica oleraceavarbotrytis) cv. Pant sugra. Journal ofPharmacognosy and Phytochemistry 8(4): 2088-2090.

Kocira, S., Szparaga, A., Kubon, M., Czerwinska, E. and Piskier. T. (2019) Morphological and biological responses of Glycine max (L.) Merr.to the use of seaweed extract. Journal Article 9(2): 93

Moraditochaee, M., Bozorgi, H.R., and Halajisani, N. (2011) Effects of vermicompost application and nitrogen fertilizer rates on fruit yield and several attributes of eggplant (Solanum melongenal 34 L.) in Iran. Journal of World Applied Sciences 15(2):174-178.

Narayanamma, M., Radha Rani, K., KameswariLalitha, P and Reddy, R.V.S.K. (2009) Effect of foliar application of micronutrients on the yield components, yield and nutrient content of bitter gourd. The Orissa Journal of Horticulture 37 (2):1-5.

Nileema S. Gore and Sreenivasa, M. N. (2011) Influence of liquid organic manures on growth, nutrient content and yield of tomato (Lycopersicones culentum Mill.) in the sterilized soil. Karnataka Journal of Agricultural Sciences 24:153-157.
Olle, M. and I. H. Williams (2013) Effective microorganisms and their influence on vegetable production-a review. The Journal of Horticultural Science and Biotechnology 88(4): 380-386.

Paramanick, B., Brahmachari, K. and Ghosh, A. (2013) Effect of seaweed saps on growth and yield improvement of green gram. Journal of Agricultural Research8:11801186.

Patil, S.V., Halikatti, S.I., Hiremath, S.M., Babalad, H.B., Sreenivasa, M.N., Hebsur, N.S. and Somanagouda, G. (2012) Effect of organics on growth and yield of chickpea (Cicer arietinum L.) in vertisols. Karnataka Journal of Agricultural Sciences 25(3): 326331.

Rengasamy, K. R. R., Kulkarni, M. G., Stirk, W. A. and Staden, J. V. (2015) Eckol Improves Growth, Enzyme Activities, and Secondary Metabolite Content in Maize (Zea mays cv. Border King). Journal of Plant Growth Regulation 34: 410-416.

Sarkar,S., Kundu, S.S. and Ghorai, D. (2014) Validation of ancient liquid organics Panchagavya and Kunapajala as plant growth promoters. Indian Journal of Traditional Knowledge 13:398-403.

Seran, T.H. and Shahardeen, R.N.M. (2013) Markettable pod yield of Vegetable Cowpea (Vignaunguiculata) as Influenced by Organic Manures Fermented with EM Solution. The Open Horticulture Journal 6: 19-23.

Shehata, S.A., Fawzy, Z.F. and El-Ramady, H.R. (2012) Response of cucumber plants to foliar application of chitosan and yeast under greenhouse. Australian Journal of Basic and Applied Sciences 6(4): 63-71.

Spinelli, F., Fiori, G. and Noferini, M. (2010) A novel type of seaweed extract as a natural alternative to the use of iron chelates in strawberry production. Scientia Horticulturae 125(3): 263-269.

Sridhar, S. and Rengasamy.R. (2010) Effect of seaweed liquid fertilizer on the growth, biochemical constituents and yield of Tageteserecta, under field trial.Journal of Phytological Research 2(6): 61-68.

Youssef, F.A., El-Segali, M.U., Abou-Taleb, S.M. and Massoud, K.W. (2019) Response of cowpea (Vignaunguiculata L.) plant to seaweed and yeast extracts. Plant Archives 19(2): 2363-2370. 